\title{
Theatre of Blood: The RSC Duchess of Malfi
}

\author{
by Erin E. Kelly. Published in 2018 Issue 1.
}

For the production: The Duchess of Malfi (2018, Swan Theatre, Royal Shakespeare Company). Performance attended: 2018-04-11. See production details at the end of the review.

RATHER THAN OPENING With THE PLAY'S Dialogue BETWEen ANTONio (PAUl WoOdson) AND His friend Delio (Greg Barnett), an exchange that establishes the contrast between the noble French court and the corrupt Italian political scene, Mari Aberg's The Duchess of Malfi begins with the title character pulling across the thrust stage a life-sized, stylized animal carcass. (I believe this was meant to be a steer, but others have described it as a bull, a pig, or as a fictional animal. Not being a large-animal veterinarian, I will not claim my species identification is definitive.)

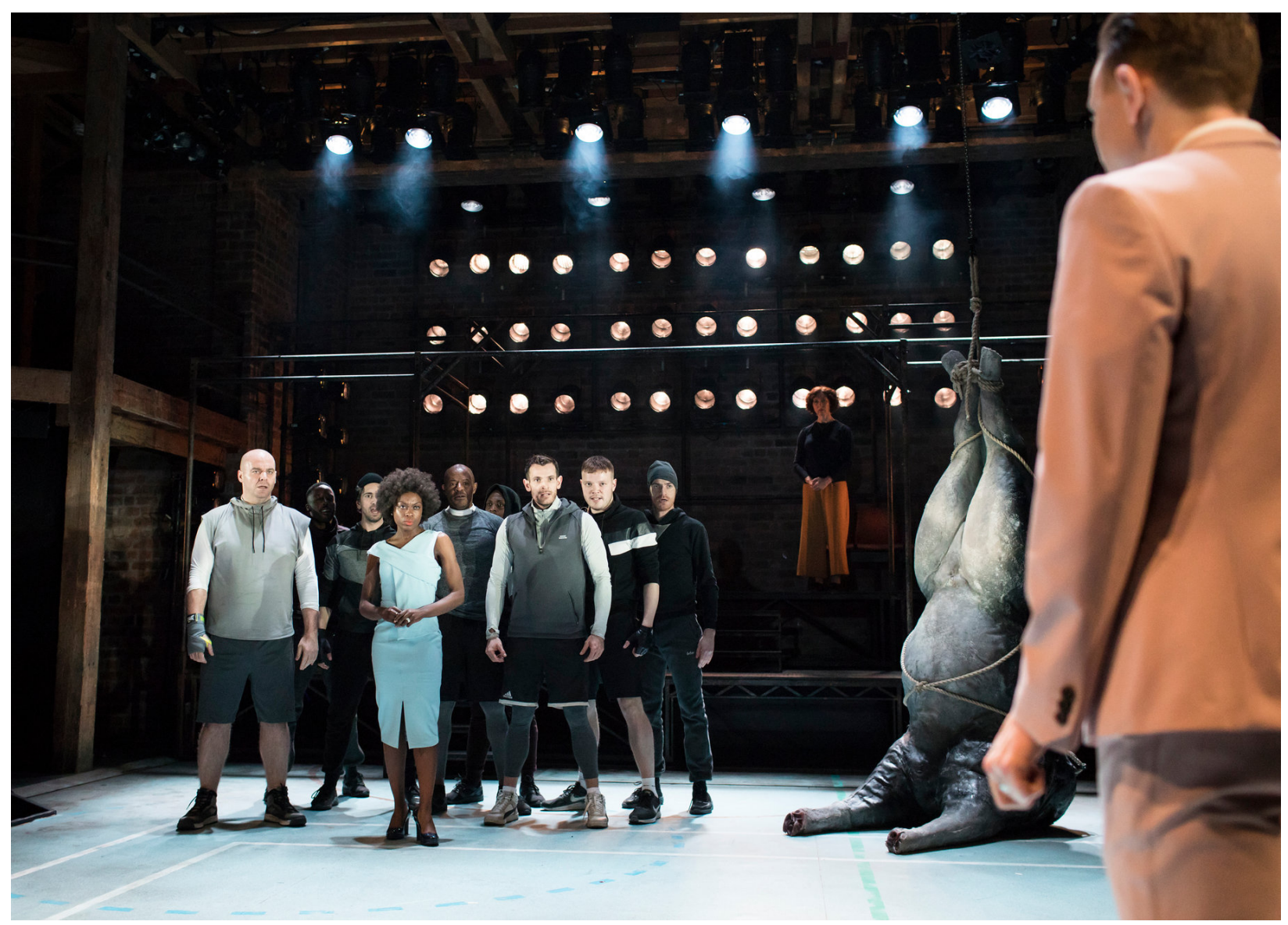

Figure 1. Joan lyiola as The Duchess and the Company. Photo by Helen Maybanks. Copyright Royal Shakespeare Company.

Her stage action was presumably meant to foreshadow the myriad ways in which this female character would find herself in a world where she is oppressed by the masculine forces of her 
dead first husband, her scheming brothers, and the patriarchy's standards for feminine virtue. By the production's end, however, I wondered whether we had more accurately been signaled that all involved in the production-including the audience-would be weighed down by unnecessary difficulties.

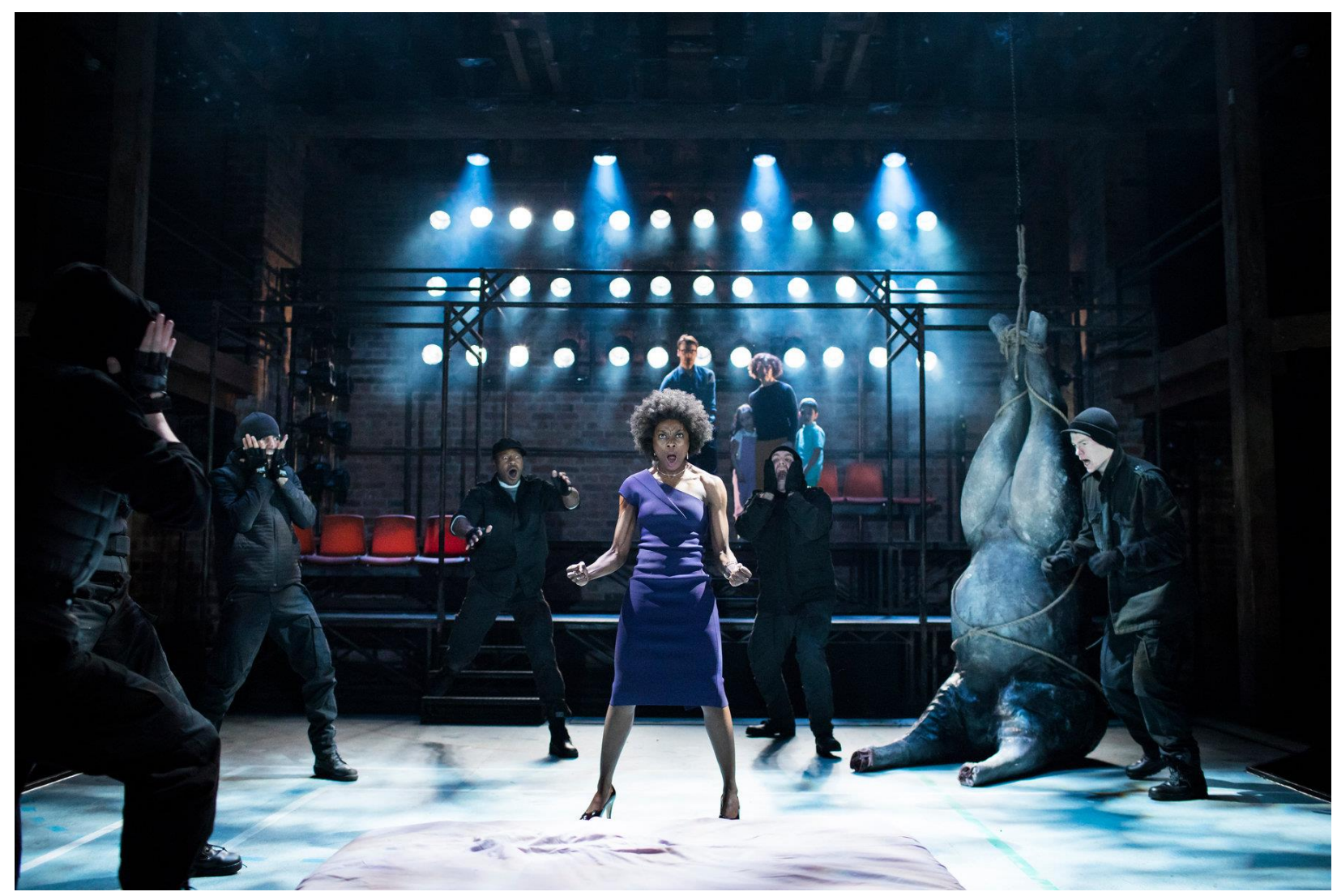

Figure 2. Joan lyiola as The Duchess. Photo by Helen Maybanks. Copyright Royal Shakespeare Company.

There were some fine scenes and excellent performances in this modern dress production. In his first moments onstage as Ferdinand, Alexander Cobb appeared so tightly wound that his subsequent prurient obsession with his sister's sexuality and eventual descent into madness seemed understandable, perhaps inevitable. Cobb's twitchy, creepy performance strongly contrasted with Chris New's Cardinal. Wearing a simple clerical collar to signal his religious office and keeping his hands tidy with immaculate white cotton gloves, this Cardinal seemed to be watching his most monstrous acts from a distance even as he committed them. Joan Iyiola as the Duchess is one of the most physically gifted performers I have seen, using her body's strength to communicate both power and the vulnerability that arise from not meeting social expectations that a woman be helpless and obedient. Her beautiful contralto voice-whether singing or speaking-had such a musical quality that one could easily understand why the play's male characters would find her fascinating. The highlight of this production, however, was Nicolas Tennant's Bosola, as the actor consistently deployed his solid physicality and vocal gruffness as a 
cover for his moral confusion and ultimate helplessness. His understated, nuanced performance helped to balance out some of the production's more over-the-top moments.

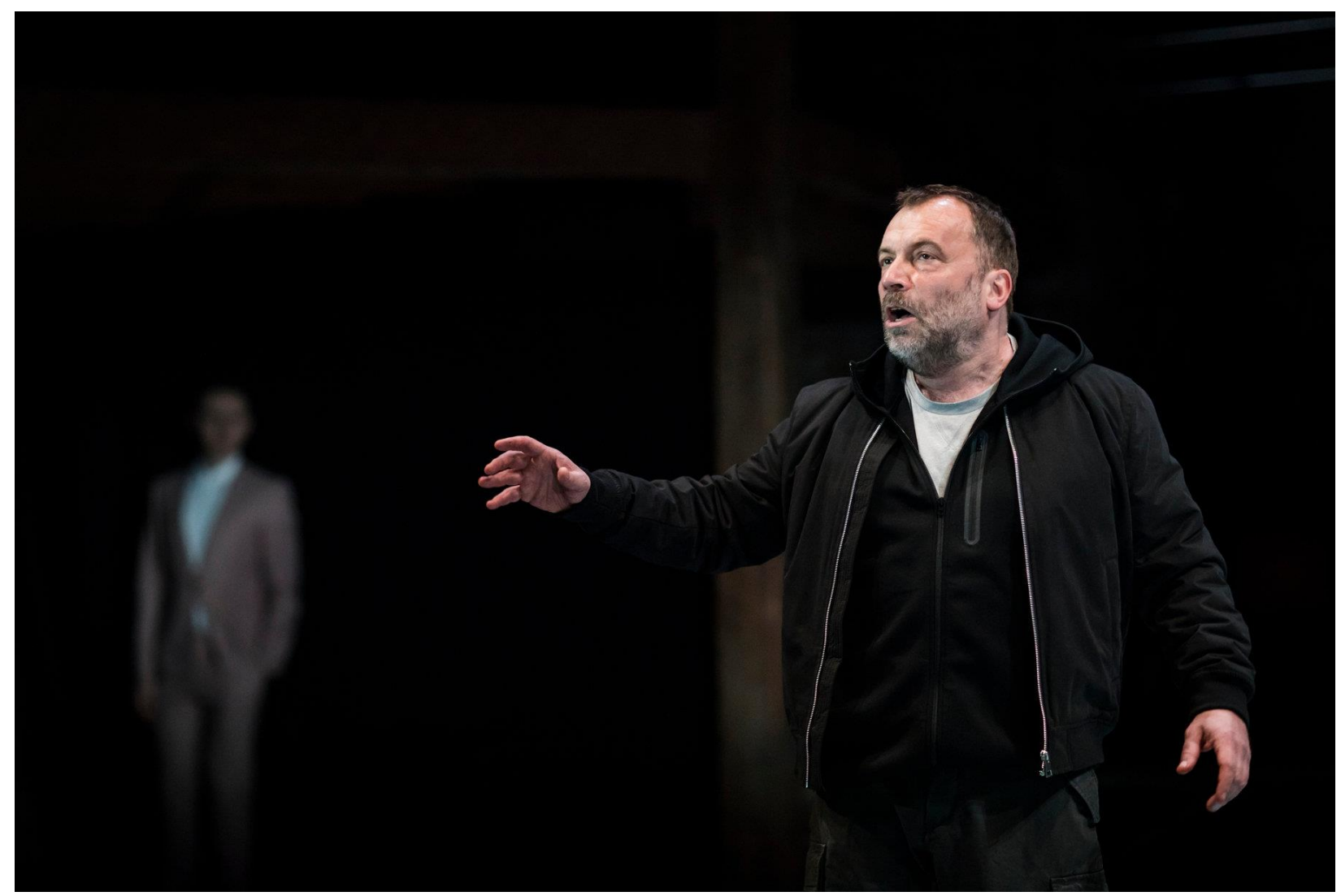

Figure 3. Nicolas Tennant as Bosola. Photo by Helen Maybanks. Copyright Royal Shakespeare Company.

These highly skilled and compelling performers created fascinating stage moments that highlighted the play's obsession with power. The scene in which the Cardinal welcomed Julia (played by Aretha Ayeh) by chiding her for protestations about her virtue while pushing her to the ground and removing one glove so that he could stimulate her to orgasm captured the sense that the play takes place in a world where sex is never divorced from power. This ugly near-rape contrasted with but also mirrored the scene in which the Duchess proposes to Antonio, here culminating in them dancing and ultimately going to bed as Ayeh in the background sang a sultry version of "I Put a Spell on You." Even when desire is mutual, the song signalled, lovers still seek to control one another. Such scenes of sexualized struggles for power seemed to lead logically to the method by which the Duchess was murdered; not merely strangled, she appeared both victim and object of desire as two men pulled on ends of a thick rope as though they were playing tugof-war with the prospect of the winner being awarded the woman whose neck is knotted in the middle of their game. 


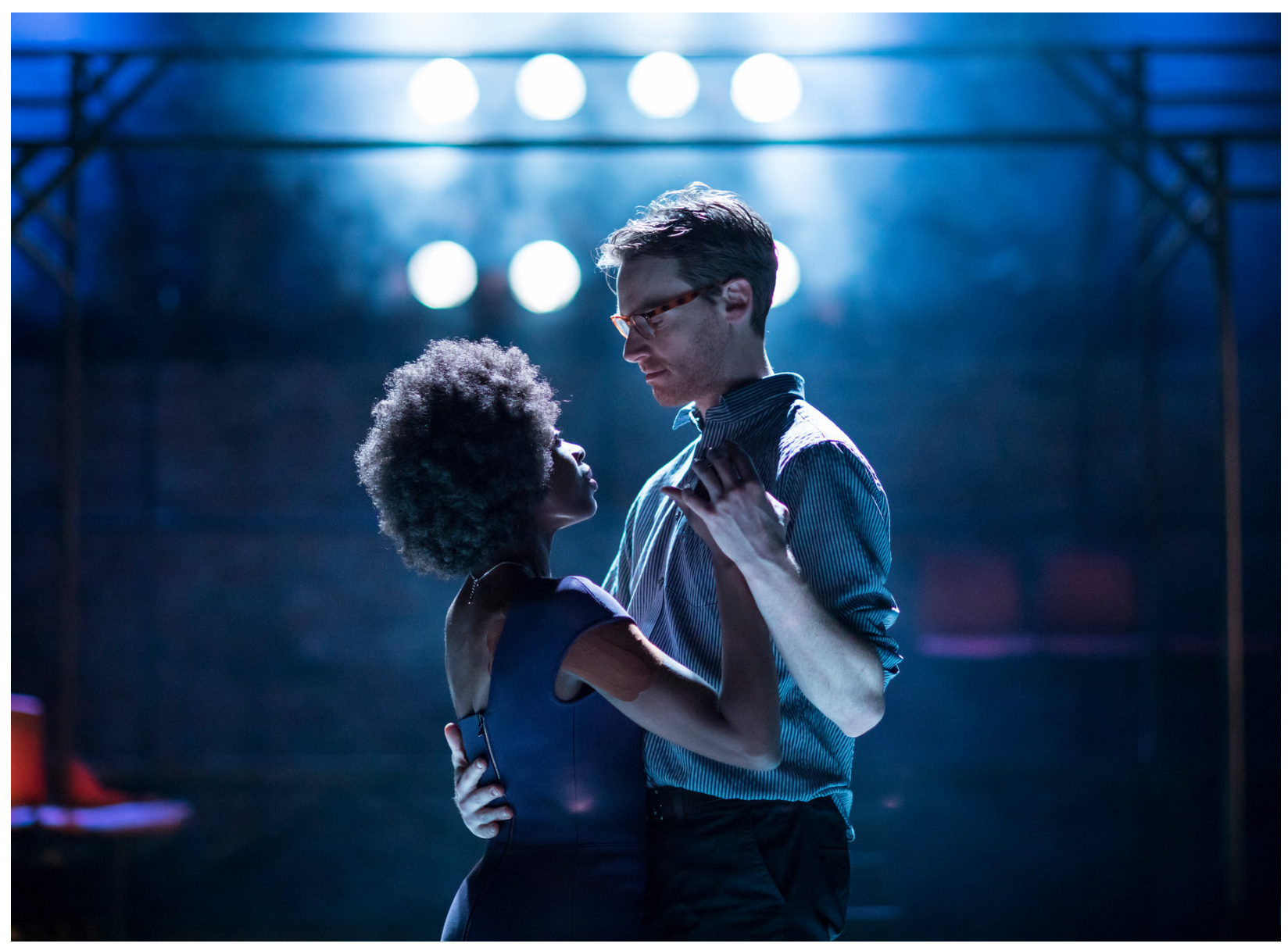

Figure 4. Joan Iyiola as The Duchess and Paul Woodson as Antonio. Photo by Helen Maybanks. Copyright Royal Shakespeare Company.

Other production choices weren't as effective, but they did fit with the concept stated in the program that Duchess is a play concerned with "masculinity and madness." Music, ranging from electric guitars to religious chant to a countertenor solo, was beautifully disturbing, but so pervasive that it sometimes obscured the play's language. Presenting the Duchess's court as comprised of strong, athletic young men who first appear engaged in choric movement combining dance, martial arts, and shows of strength—performed on a stage that visually echoed a basketball court-established the sense that a group of men can be threatening both to its members and to any outsiders. Dressing this company in athletic gear, however, made it difficult to understand how these men might function in a court setting, and their clear visual contrast with the play's very powerful high status men - the muscly corps in black and grey while the wiry Ferdinand and Cardinal appear in jewel tones-was fascinating even if it didn't seem to fit with the production's attempt to draw a clear line between men and women, masculine and feminine power. 


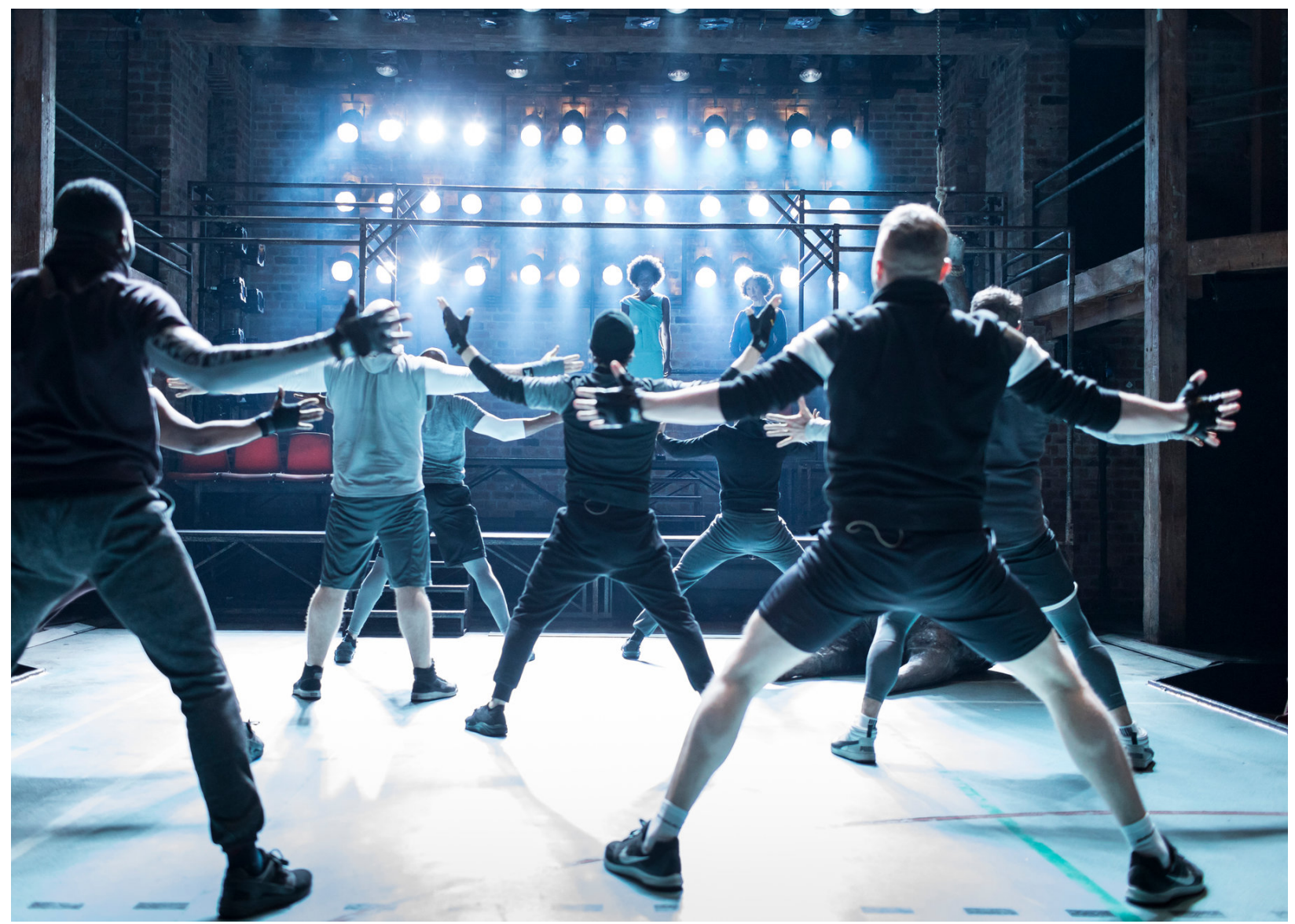

Figure 5. The Company. Photo by Helen Maybanks. Copyright Royal Shakespeare Company.

But some staging choices were simply baffling. While modern theatre lighting makes it possible to plunge an audience into darkness, doing so wrecks the scene in which Ferdinand presents his captive sister with what appears to be her husband's severed hand. Unless we can see the Duchess kiss the hand and subsequently watch her discover why it is "very cold," it isn't clear what is happening, much less how sadistic Ferdinand has become. The audience's ability to see was similarly compromised when rather than following the play's suggestion that the Duchess be presented with "the artificial figures of Antonio and his children, appearing as if they were dead," the production decided to show what looked like two body-sized rubber Halloween masks. Perhaps these were supposed to be flayed skin, but these "bodies" looked completely unreal and, more problematically, unidentifiable as anyone in particular. In a production that otherwise seemed eager to shock, it was surprising that these scenes of horror were rendered so ineffectively.

Other stage choices seemed detrimental to both audience and actors. As mentioned previously, the production opened with the Duchess dragging a dead animal across the stage; its hind legs were hooked to a winch and the body hefted up as though it was hanging in a meat locker. This 
created a memorable but ill-conceived stage image, since the large hulk of rubbery flesh occupied at least $10 \%$ of the stage. The bulk of this object limited stage action and certainly blocked sightlines for those seated closest to it. The sense of the stage as cramped was further compounded when a bed was pulled out to signify the Duchess's private chambers and then remained present until after the Duchess's murder. Rather than suggesting that the play was taking place in an increasingly constricted setting, these large set pieces simply made it difficult for actors to move across or to use as playing space much of the thrust.

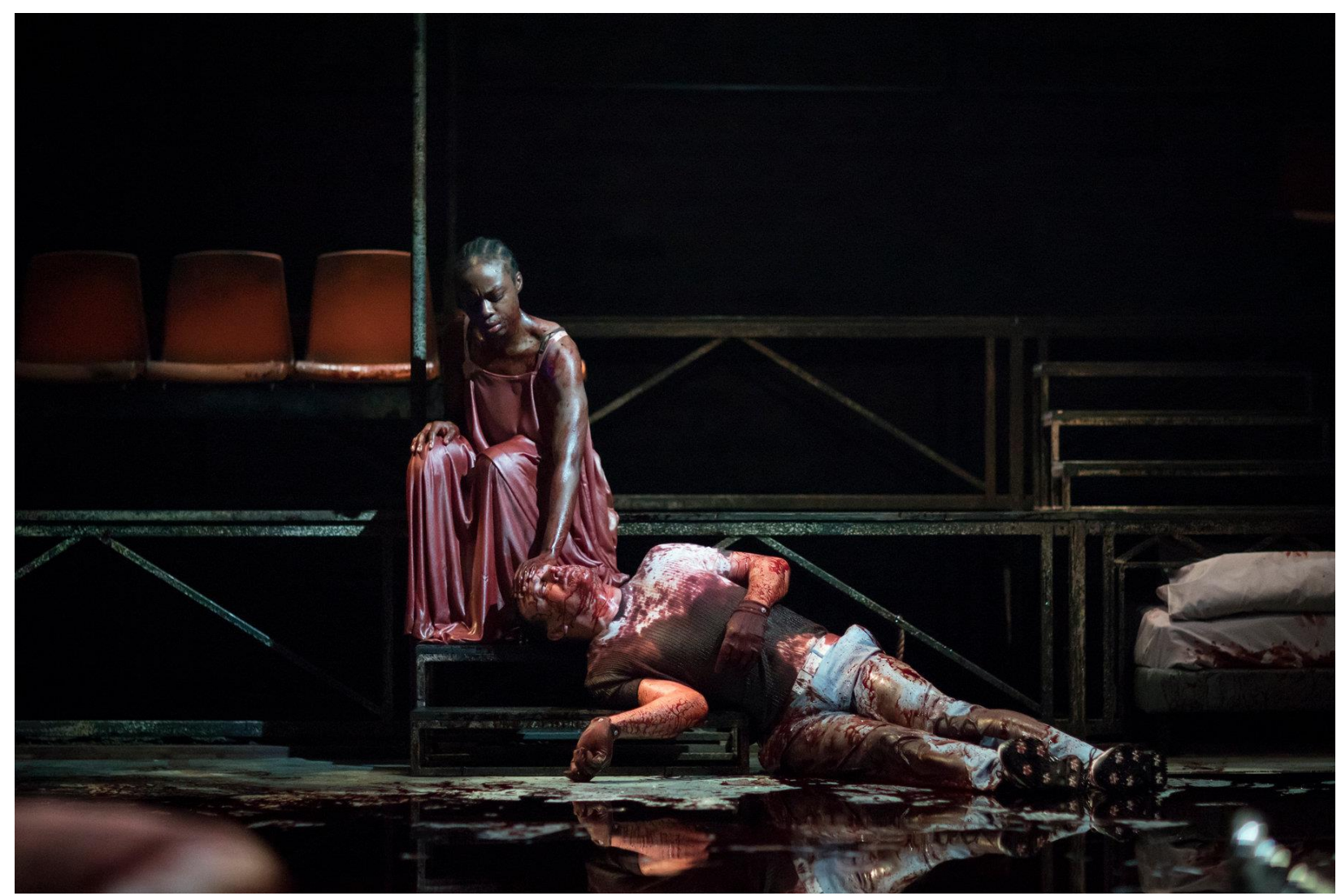

Figure 6. Joan Iyiola as The Duchess and Chris New as The Cardinal. Photo by Helen Maybanks. Copyright Royal Shakespeare Company.

The ultimate sacrifice of performance to spectacle, however, came after-in a fit of rage upon learning of his sister's marriage to her steward-Ferdinand stabbed the carcass. From that point on, blood dripped from the monstrous sack of skin until, by the final scene, it covered most of the stage. While this staging decision created some powerful images-particularly of the Duchess smeared in blood-it also reduced a number of scenes full of stunning language and shocking violence to a perilous display of actors sliding awkwardly in sticky, wet puddles. The audience members sitting in the first rows were actually offered a splash warning and blankets by ushers as they returned to the theatre after the interval, and it is not clear how those people could experience the final scene without being distracted by the thought of future laundry challenges. 
The emphasis on masculinity, blood, and spectacle in this production might not have been to my taste, but all would be excusable if I thought it served Webster's play. Significant cuts to the text, however, meant that some aspects of the play would be almost incomprehensible to anyone not familiar with Duchess of Malfi. To give but one example, cutting Julia's husband from the production leaves little sense of how Julia winds up associated with the Cardinal, and the removal of lines in which Julia attempts to seduce Bosola leaves her with no clear motivation for asking the Cardinal to share his secrets with her. Even more problematic was this production's reduction of the relationship between Delio and Antonio to a handful of lines, including the removal of Delio from the play's final scene. Rather than ending with Delio promising to establish Antonio's son as his mother's rightful heir, this production concludes with Bosola's death. Duchess of Malfi doesn't have a happy, orderly ending even when Delio's speech is included, but the absence of any resolution other than a pile of bodies steeping in a puddle of blood made this play's ending a spectacle of rather than a meditation on violence. While some might have found the text's revision (or redaction?) into a tale of male violence against women a revelation, I longed for what was missing. Webster's play offers complex explorations into many kinds of hierarchical power structure-not just related to gender but also class, reputation, and lineage-and diminishing those themes burdens the audience with the experience of witnessing a massacre rather than a tragedy. 


\section{Production Details}

\section{General}

Title

Year

Theatre Company

Theatre

\section{Cast}

DOCTOR
JULIA
DELIO
OFFICER
RODERIGO
FERDINAND
SiLVIO
COUNTER TENOR
CARIOLA
GRISOLAN
OfFICER
THE DUCHESS
THE CARDINAL
BOSOLA
ANTONIO

\section{Creatives}

DiRECTOR
DESIGNER
Lighting
MusiC
SOUND
MOVEMENT
FightS
FIGHTS

\author{
The Duchess of Malfi \\ 2018 \\ Royal Shakespeare Company \\ Swan Theatre
}

\author{
JEFF ALEXANDER \\ ARETha AyeH \\ GREG BARNETT \\ GRAEME BROOKES \\ WILL BROWN \\ AleXANDER CobB \\ ASHLEY GAYLE \\ FRANCIS GUSH \\ AMANDA HADINGUE \\ RICHARD HURST \\ SOLOMON ISRAEL \\ JOAN IYIOLA \\ CHRIS NEW \\ NiCOLAS TENNANT \\ PAUL WOODSON
}

MARIA ABERG
NAOMI DAWSON
NATASHA CHIVERS
ORLANDO GOUGH
CLAIRE WINDSOR
AYSE TASHKIRAN
RACHEL BOWN-WILLIAMS
RUTH COOPER-BROWN

